\title{
Final Score Equals Sum of Column Totals
}

National Cancer Institute

\section{Source}

National Cancer Institute. Final Score Equals Sum of Column Totals. NCI Thesaurus.

Code C157022.

A final test score, as summed from individual column totals. 